\title{
Pengaruh Jumlah Nasabah Peminjam Terhadap Perkembangan Aset Badan Usaha Milik Desa (Bumdes) Lestari Di Desa Kumain Kecamatan Tandun Kabupaten Rokan Hulu
}

\author{
RISMAN \\ Sekolah Tinggi Ilmu Ekonomi Riau (STIER) \\ Jln. HR. Subrantas 57 Panam Pekanbaru 28293 Telp. (0761) 63237 \\ E-mail : akbar_stier@yahoo.com
}

\begin{abstract}
Asset development becomes an achievement that should be achieved in a business. BUMDes is a pro-people business entity and provides convenience for the people in obtaining capital. BUMDes assets become a hope in its management, the last few time BUMDes assets have decelerated. On the other hand the number of customers also experienced fluctuations, this study tried to connect the development amount with the development of BUMDes assets. Through quantitative research using secondary data and analyzed by using simple linier regression analysis program with the help of SPSS program obtained the result that the value of $\mathrm{t}$-count $=9.038$ is greater than the critical value or shown by t-table of 2.503 . then the hypothesis of this study can be accepted and proved that the number of customers significantly affect the development of assets in the State Owned Enterprises (BUMDes) Lestari.
\end{abstract}

Keywords: Increasing Number ff Customers, Development of BUMDes Assets

Pembangunan dan pengembangan sektor ekonomi secara berkelanjutan mutlak harus dilakukan, sebagaimana tujuan negara Indonesia yang diamanatkan dalam Pembukaan Undang-Undang Dasar 1945 antara lain adalah memajukan kesejahteraan umum. Kesejahteraan umum atau kesejahteraan rakyat dapat ditingkatkan jika kemiskinan dapat dikurangi, sehingga untuk meningkatkan kesejahteraan umum dapat dilakukan melalui upaya penanggulangan kemiskinan. Masalah kemiskinan dan kesenjangan ini secara ekonomi, baik antar golongan maupun antar wilayah (perdesaan dan perkotaan) sangat mencolok.

Mengingat sebagian besar penduduk Indonesia tinggal diperdesaan, maka perlu dikedepankan pembangunan untuk perbaikan perekonomian desa dan meningkatkan kemandirian masyarakat serta mengentaskan kemiskinan. Dalam pengentasan kemiskinan, Negara Indonesia memiliki bermacam strategi salah satunya adalah penyaluran kredit melalui Badan usaha Milik Desa ( BUMDes )
Tujuan penyaluran kredit bagi masyarakat adalah untuk membantu masyarakat dalam pembentukan modal kerja dalam melakukan usaha dalam rangka meningkatkan taraf hidup yang lebih baik, seperti terpenuhinya berbagai kebutuhan pokok, kebutuhan pendidikan, kesehatan dan lainya.

Pemerintah telah memberikan solusi perubahan, pada era reformasi tahun 1999 di putuskan UU 22/1999 (pasal 108) yang mendorong pembentukan badan usaha atau lembaga yang digunakan untuk mengelola sumber dayanya secara efisien. Lalu diperjelas oleh PP 72/2005 (pasal 78 ayat 1) yang menyatakan bahwa "Dalam peningkatan pendapatan masyarakat dan desa, Pemerintahan Desa dapat mendirikan Badan Usaha Milik Desa", karena desa perlu suatu lembaga untuk mengelola potensinya untuk meningkatkan perekonomian, kemandirian dan kesejahteraan masyarakat desa.

Dalam pendirian BUMDes ini dikenal empat tahapan; Pertama, 
pemerintah desa dan masyarakat bersepakat mendirikan BUMDes, lalu diadakan Pengelolaan BUMDes dan penetapan Persyaratan Pemegang Jabatan, diadakan pula Monitoring dan Evaluasi, dan yang terakhir diadakan Pelaporan Pertanggungjawaban Pengelola. Dalam kegiatan harian maka pengelola harus mengacu pada tata aturan yang sudah disepakati bersama sebagaimana yang telah tertuang dalam Anggaran Dasar dan Anggaran Rumah Tangga (AD/ART) BUMDes, serta sesuai prinsip-prinsip tata kelola BUMDes.

Sebagai salah satu lembaga ekonomi yang beroperasi dipedesaan, BUMDes harus memiliki perbedaan dengan lembaga ekonomi pada umumnya. Ini dimaksudkan agar keberadaan dan kinerja BUMDes mampu memberikan kontribusi yang signifikan terhadap peningkatan kesejahteraan warga masyarakat.

Badan Usaha Milik Desa (BUMDes) Lestari adalah Badan Usaha yang dimiliki oleh Pemerintah Desa Kumain yang pengelolaanya diserahkan kepada pengelola BUMDes yang telah ditunjuk oleh Pemerintah Desa dengan Kesepakatan dan mufakat melalui proses musyawarah Desa. BUMDes Lestari desa Kumain sedikitnya mempunyai 3 kegiatan utama, yaitu :

1. Menerima dana dari masyarakat dalam bentuk tabungan

2. Menyalurkan dana kepada yang membutuhkan dalam bentuk pinjaman

Pembiayaan, pembelian barang barang kebutuhan masyarakat melalui pesanan. Beberapa kajian asset dapat diperoleh dari kinerja pengelola. Menurut Fatkhurahman (2016) bahwa karya seorang pengelola industri kecil merupakan bentuk kreatifitas yang perlu dikembangkan dan perlu mendapatkan perhatian. Karena karya diperoleh dari sebuah keinginan atau kemauan. Kemauan untuk berbuat merupakan suatu keadaan yang berada dalam diri. Selain itu juga keberhasilan usaha ada kaitannya dengan keberanian menanggung resiko sebagaimana dijelaskan oleh Pailis Jurnal Daya Saing
(2016) bahwa: The courage to take this risk will make employers unlucky and this part of the achievements that afford showed in the attempt. Later in the context of theoretical construct feat trying.

Penelitian yang dilakukan oleh Mahendra (2015) dengan judul "Analisis Kinerja Badan Usaha Milik Desa (BUMDes) (Studi di Kabupaten Tulungagung) "Universitas Brawijaya" Penelitian ini bertujuan untuk mengidentifikasi kinerja Badan Usaha Milik Desa (BUMDes) dan menganalisis implikasi Badan Usaha Milik Desa (BUMDes) terhadap kemandirian ekonomi pada Kabupaten Tulungagung. Metode penelitian menggunakan pendekatan kualitatif, dengan jenis studi kasus (case study). Sumber data berasal dari wawancara, observasi, dan dokumendokumen. Teknik analisis data yang digunakan adalah analisis model interaktif Miles and Huberman yaitu mereduksi data, menyajikan data serta menarik kesimpulan. Dari hasil penelitian ini di deskripsikan bahwa kinerja BUMDes ditinjau dari Aspek Pelayanan dapat melayani masyarakat dengan baik, ditinjau dari Aspek Akuntabilitas dapat mewadahi berbagai program pemerintah, ditinjau dari Aspek Peningkatan Taraf Hidup dapat memiliki penghasilan tambahan dari BUMDes, ditinjau dari Aspek Ketaatan terhadap Undang-undang telah dilaksanakkan. Sedangkan implikasinya terhadap Kemandirian Ekonomi Mayarakat yaitu, kinerja BUMDes terkait aspek Pelayanan berimplikasi terhadap Kemandirian Ekonomi Mayarakat, kinerja BUMDes terkait aspek Akuntabilitas berimplikasi terhadap Meningkatnya Pendapatan Asli Desa, kinerja BUMDes terkait aspek Peningkatan Taraf Hidup berimplikasi terhadap pertumbuhan dan pemerataan ekonomi pedesaan, kinerja BUMDes terkait aspek Ketaatan Peraturan Perundangundangan berimplikasi dalam kemampuan dalam pengelolaan potensi desa.

Penelitian selanjutnya yang dilakukan oleh Disty Purnamasari (2015)

p.ISSN: $2407-800 X \quad$ e.ISSN: 2541-4356 
dengan judul “ Peran Badan Usaha Milik Desa (Bumdes) Dalam Meningkatkan Kesejahteraan Masyarakat Desa (Studi Kasus Desa Minggirsari, Kecamatan Kanigoro, Kabupaten Blitar)" Dalam mencapai kesejahteraan dikalangan warga desa tidak mudah, pola pikir warga desa yang masih tradisional membuat, peningkatan kesejahteraan ditingkat pedesaan berjalan lambat, karena itu pemerintah pusat berusaha membantu warga desa dengan membentuk lembaga yang didalamnya dapat menaungi kegiatan ekonomi warga masyarakat. Disisi lain pelaksanaan dari kegiatan dilembaga ini tidak bisa lepas peran pemerintah desa yang memberikan dorongan untuk pengurus agar bersikap professional dalam memberikan pelayanan bagi warganya. Dari kegiatan tersebut telah terjadi peningkatan ekonomi bagia warga desa dan juga desa yang terbantu oleh adanya pengelolaan lembaga tersebut, sehingga desa mendapatkan pembagian hasil usaha yang membantu dalam meningkatkan PAD desa. Pelaksanaan peran di BUMDes ini dilaksanakan menjadi dua peran yakni peran fasilitator dan katalisator. Dari pelaksanaa peran ini, banyak warga telah terbantu untuk pengembangan usaha dan lain-lain. Disisi lain, kegiatan lain yang dilaksanakan BUMDes untuk membantu warga dalam meningkatkan kesejahteraannya yakni dengan mengalokasikan dana $15 \%$ untuk kegiatan bantuan social. Kegiatan dari unit usaha dilaksanakan dengan sistem kemitraan dengan sistem bagi hasil sebesar $70 \%$ untuk warga dan $30 \%$ untuk BUMDes. Selain itu, beberapa unit usaha yang berdiri juga membantu warga khususnya petani.

Badan Usaha Milik Desa (BUMDes) adalah lembaga usaha desa yang dikelola oleh masyarakat dan pemerintahan desa dalam upaya memperkuat perekonomian desa dan dibentuk berdasarkan kebutuhan dan potensi desa. BUMDes menurut Undangundang nomor 32 Tahun 2004 tentang Pemerintahan Daerah didirikan antara lain dalam rangka peningkatan Pendapatan Asli Desa (PADesa). Sebagai salah satu lembaga ekonomi yang beroperasi dipedesaan, BUMDes harus memiliki perbedaan dengan lembaga ekonomi pada umumnya. Ini dimaksudkan agar keberadaan dan kinerja BUMDes mampu memberikan kontribusi yang signifikan terhadap peningkatan kesejahteraan warga desa. Disamping itu, supaya tidak berkembang sistem usaha kapitalistis di pedesaan yang dapat mengakibatkan terganggunya nilai-nilai kehidupan bermasyarakat. Terdapat 7 (tujuh) ciri utama yang membedakan BUMDes dengan lembaga ekonomi komersial pada umumnya yaitu: 1. Badan usaha ini dimiliki oleh desa dan dikelola secara bersama; 2. Modal usaha bersumber dari desa $(51 \%)$ dan dari masyarakat $(49 \%)$ melalui penyertaan modal (saham atau andil); $\quad 3$ Operasionalisasinya menggunakan falsafah bisnis yang berakar dari budaya lokal (local wisdom); 4. Bidang usaha yang dijalankan didasarkan pada potensi dan hasil informasi pasar; 5 . Keuntungan yang diperoleh ditujukan untuk meningkatkan kesejahteraan anggota (penyerta modal) dan masyarakat melalui kebijakan desa (village policy); 6 . Difasilitasi oleh Pemerintah, Pemprov, Pemkab, dan Pemdes; 7. Pelaksanaan operasionalisasi dikontrol secara bersama (Pemdes, BPD, anggota). BUMDes sebagai suatu lembaga ekonomi modal usahanya dibangun atas inisiatif masyarakat dan menganut asas mandiri. Ini berarti pemenuhan modal usaha BUMDes harus bersumber dari masyarakat. Meskipun demikian, tidak menutup kemungkinan BUMDes dapat mengajukan pinjaman modal kepada pihak luar, seperti dari Pemerintah Desa atau pihak lain, bahkan melalui pihak ketiga. Ini sesuai dengan peraturan per undang-undangan (UU 32 tahun 2004 tentang Pemerintahan Daerah Pasal 213 ayat 3). Penjelasan ini sangat penting untuk mempersiapkan pendirian BUMDes, karena implikasinya akan bersentuhan dengan pengaturannya dalam Peraturan Daerah (Perda) maupun Peraturan Desa (Perdes).

Empat tujuan utama pendirian BUMDes adalah: 1. Meningkatkan perekonomian desa; 2. Meningkatkan

p.ISSN: $2407-800 X \quad$ e.ISSN: 2541-4356 
pendapatan asli desa; 3. Meningkatkan pengolahan potensi desa sesuai dengan kebutuhan masyarakat; 4. Menjadi tulang punggung pertumbuhan dan pemerataan ekonomi pedesaan. Pendirian dan pengelolaan Badan Usaha Milik Desa (BUMDes) adalah merupakan perwujudan dari pengelolaan ekonomi produktif desa yang dilakukan secara kooperatif, partisipatif, emansipatif, transparansi, akuntabel, dan sustainable. Oleh karena itu, perlu upaya serius untuk menjadikan pengelolaan badan usaha tersebut dapat berjalan secara efektif, efisien, profesional dan mandiri untuk mencapai tujuan. BUMDes dilakukan dengan cara memenuhi kebutuhan (produktif dan konsumtif) masyarakat melalui pelayanan distribusi barang dan jasa yang dikelola masyarakat dan Pemdes. Pemenuhan kebutuhan ini diupayakan tidak memberatkan masyarakat, mengingat BUMDes akan menjadi usaha desa yang paling dominan dalam menggerakkan ekonomi desa. Lembaga ini juga dituntut mampu memberikan pelayanan kepada non anggota (di luar desa) dengan menempatkan harga dan pelayanan yang berlaku standar pasar. Artinya terdapat mekanisme kelembagaan/tata aturan yang disepakati bersama, sehingga tidak menimbulkan distorsi ekonomi di pedesaan disebabkan usaha yang dijalankan oleh BUMDes. Dinyatakan di dalam undangundang bahwa BUMDes dapat didirikan sesuai dengan kebutuhan dan potensi desa. Apa yang dimaksud dengan "kebutuhan dan potensi desa" adalah: a. Kebutuhan masyarakat terutama dalam pemenuhan kebutuhan pokok; b. Tersedia sumberdaya desa yang belum dimanfaatkan secara optimal terutama kekayaan desa dan terdapat permintaan dipasar; c. Tersedia sumber daya manusia yang mampu mengelola badan usaha sebagai aset penggerak perekonomian masyarakat; d. Adanya unit-unit usaha yang merupakan kegiatan ekonomi warga masyarakat yang dikelola secara parsial dan kurang terakomodasi.

Prinsip-prinsip pengelolaan BUMDes penting untuk diuraikan agar difahami dan dipersepsikan dengan cara yang sama oleh pemerintah desa, anggota (penyerta modal), BPD, Pemkab, dan masyarakat. Terdapat 6 (enam) prinsip dalam mengelola BUMDes yaitu: 1. Kooperatif, Semua komponen yang terlibat di dalam BUMDes harus mampu melakukan kerjasama yang baik demi pengembangan dan kelangsungan hidup usahanya. 2. Partisipatif. Semua komponen yang terlibat di dalam BUMDes harus bersedia secara sukarela atau diminta memberikan dukungan dan kontribusi yang dapat mendorong kemajuan usaha BUMDes. 3. Emansipatif. Semua komponen yang terlibat di dalam BUMDes harus diperlakukan sama tanpa memandang golongan, suku, dan agama. 164. Transparan. Aktivitas yang berpengaruh terhadap kepentingan masyarakat umum harus dapat diketahui oleh segenap lapisan masyarakat dengan mudah dan terbuka. 5 . Akuntabel. Seluruh kegiatan usaha harus dapat dipertanggungjawabkan secara teknis maupun administratif. 6. Sustainabel. Kegiatan usaha harus dapat dikembangkan dan dilestarikan oleh masyarakat dalam wadah BUMDes. Terkait dengan implementasi Alokasi Dana Desa (ADD), maka proses penguatan ekonomi desa melalui BUMDes diharapkan akan lebih berdaya. Hal ini disebabkan adanya penopang yakni dana anggaran desa yang semakin besar. Sehingga memungkinkan ketersediaan permodalan yang cukup untuk pendirian BUMDes. Hal utama yang penting dalam upaya penguatan ekonomi desa adalah memperkuat kerjasama (cooperatif), membangun kebersamaan atau menjalin kerekatan disemua lapisan masyarakat desa, sehingga itu menjadi daya dorong (steam engine) dalam upaya pengentasan kemiskinan, pengangguran, dan membuk akses pasar. (Bagus Setiawan, 2007:1-14)

Beberapa pengertian Kredit antara lain: (1) Penyerahan barang jasa atau utang dari suatu pihak atas dasar kepercayaan kepada pihak lain dengan janji membayar dari penerima kredit pada tanggal yang telah disepakati kedua belah pihak; (2) 
kredit menyediakan uang atau tagihan yang dapat dipersamakan dengan itu, berdasarkan persetujuan atau kesepakatan pinjam meminjam antara bank dengan pihak lain yang mewajibkan pihak peminjam untuk melunasi hutangnya setelah jangka waktu tertentu dengan imbalan atau bagi hasil; (3) penyerahan nilai ekonomi sekarang atas kepercayaan dengan harapan mendapat kembali suatu nilai ekonomi yang sama dikemudian hari; (4) suatu tindakan atas dasar perjanjian dimana dalam perjanjian tersebut terdapat jasa dan balas jasa yang keduanya dipisah atas unsur waktu, serta; (5) 20 suatu hak, yang dengan hak tersebut seseorang dapat mempergunakannya untuk tujuan tertentu, dalam batas waktu tertentu, dan atas pertimbangan tertentu pula. (Veithzal Rivai, Andria Permata Veithzal \& Ferry N. Idroes, 2007:438) Pengertian Kredit dalam Pasal 1 angka 11 UU Perbankan disebutkan sebagai berikut: Kredit adalah penyediaan uang atau tagihan yang dapat dipersamakan dengan itu, berdasarkan persetujuan atau kesepakatan pinjam meminjam antara bank dengan pihak lain yang mewajibkan pihak peminjam untuk melunasi utangnya setelah jangka waktu tertentu dengan pemberian bunga. (Gatot Supramono, 2009:153) Kebijakan kredit adalah merupakan pedoman yang ditempuh oleh perusahaan dalam menentukan apakah kepada seorang langganan akan diberikan kredit dan kalau diberikan kepada banyak atau berapa banyak kredit yang akan diberikan tersebut. Sedangkan Standar Kredit adalah Kriteria minimum yang harus dipenuhi oleh seorang langganan sebelum dapat diberikan kredit. (Lukman Syamsudin, 2011:256) Adapun Unsur-unsur Kredit adalah : 1. Kepercayaan Pemberi kredit percaya bahwa kredit yang diberikan akan diterima kembali dalam jangka waktu tetentu dimasa yang akan datang. 2. Waktu Ada jangka waktu yang terdapat antara saat pemberian kredit dengan saat pengembalian kredit. 3. Degree of risk Suatu tingkat resiko yang akan dihadapi sebagai akibat dari adanya jangka waktu yang memisahkan pemberian kredit dengan kontraprestasi yang akan diterima di masa yang akan datang. 4 . Prestasi Objek kredit yang diberikan dalam bentuk uang atau barang. 5. Balas jasa Pendapatan atas pemberian kredit bank dapat berupa bunga, provesi dan biaya administrasi kredit. Hal tersebut merupakan balas jasa yang diterima dari adanya kredit. (M. Ramli Faud \& M. Rustan, 2005:131132)

Pada dasarnya terdapat dua tujuan yang saling berkaitan dengan kredit, yaitu sebagai berikut: a. Profitabilitas, yaitu tujuan untuk memperoleh hasil kredit berupa keuntungan yang diraih dari bunga yang harus dibayar oleh debitur. Oleh karena itu, bank hanya akan menyalurkan kredit kapada usaha yang diyakini mampu dan mau mengembalikan kredit yang telah diterimanya. b. Safety, keamana dari prestasi atau fasilitas yang diberikan harus benar- benar terjamin sehingga tujuan profitability dapat benar-benar tercapai tanpa hambatan yang berarti. Keamanan ini dimaksudkan agar prestasi yang diberikan dalam bentuk uang, barang atau jasa itu betul-betul 22 terjamin pengembaliannya sehingga keuntungan yang diharap dapat menjadi kenyataan. Kredit mempunyai peranan yang sangat penting dalam perekonomian. Secara garis besar manfaat kredit dalam perekonomian, perdagangan, dan keuangan yaitu: 1. Meningkatka untility (daya guna) dari modal atau uang. 2. Meningkatka untility (daya guna) suatu barang. 3. Meningkatkan peredaran dan lalu lintas uang. 4. Menimbulkan gairah berusaha masyarakat. 5. Alat stabilitas ekonomi. 6. Jembatan untuk meningkatkan pendapatan nasional. 7. Sebagai alat meningkatkan hubungan ekonomi internasional. (Veithzal Rivai, Andria Permata Veithzal \& Ferry N. Idroes, 2007:438)

Menurut Djaslim Saladin (1994) dalam bukunya "Dasar-Dasar Manajemen Pemasaran Bank" yang dikutip dari "Kamus Perbankan" menyatakan bahwa "Nasabah adalah orang atau badan yang mempunyai rekening simpanan atau pinjaman pada bank".

p.ISSN: $2407-800 X \quad$ e.ISSN: 2541-4356 


Kemudian menurut Komaruddin
(1994) dalam "Kamus Perbankan"
menyatakan bahwa "Nasabah adalah
seseorang atau suatu perusahaan yang
mempunyai rekening koran atau deposito
atau tabungan serupa lainnya pada sebuah
bank".

Pendapat lain nasabah adalah orang atau sekelompok orang yang melakukan kegiatan transaksi pada sebuah lembaga keuangan atau juga sekelompok individu atau sekelompok orang yang melakukan kerjasama dalam bentuk keuangan. (Yusak gumelar Pada 2016-01-13)

Sesuai uraian diatas penulis menyimpulkan bahwa nasabah BUMDes adalah orang orang atau individu yang mengadakan transaksi simpanan atau pinjaman yang terjadi pada Badan Usaha Milik Desa (BUMDes), sedangkan pada penelitian ini penulis lebih melihat pada nasabah dari segi pinjaman.

Aset adalah semua hak yang dapat digunakan dalam operasi perusahaan. Yang dapat dimasukkan ke dalam kolom a set salah satunya adalah gedung atau bangunan. Jadi kalau suatu perusahaan memiliki gedung senilai satu miliar rupiah, maka asset yang dihitung adalah satu miliar rupiah itu. Selain gedung, yang bisa dihitung sebagai asset bisa termasuk: merk dagang, paten teknologi, uang kas, mobil, Aset dipahami sebagai harta total. Namun biasanya untuk keperluan analisis dirinci menjadi beberapa kategori, seperti:
1. Aset lancar
2. Investasi jangka panjang
3. Aset tetap
4. Aset tidak berwujud
5. Aset pajak tangguhan
6. Aset lain

Daftar aset dalam neraca disusun menurut tingkat likuiditasnya, mulai dari yang paling likuid hingga yang tidak likuid. Aktiva pada neraca disajikan pada sisi kiri secara berurutan dari atas ke bawah. Penyusunan neraca dimulai dari yang paling likuid (lancar), yaitu mulai dari aktiva lancar, aktiva tetap dan seterusnya. Komponen aktiva lancar menurut Kasmir (2008:31) sebagai berikut: "kas, surat-surat berharga, piutang, persediaan, dan sebagainyaKomponen aktiva tetap menurut Kasmir sebagai berikut: "Tanah, bangunan, mesin, kendaraan, peralatan, dan lainnya" (2008:32)

Berdasarkan teori di atas aktiva disusun secara berurutan dari mulai yang likuid sampai yang kurang likuid atau yang gampang dengan mudah diuangkan. Bagi manajemen, di dalam membaca neraca, nilai aset perlu dicermati karena menjadi dasar pengukuran prestasi keuangan perusahaan. Ukuran ini menjadi pembanding prestasi sesuatu perusahaan dengan prestasi perusahaan yang lain dalam hal yang sama, apakah lebih baik atau tidak, sehingga dapat menjadi dasar keputusan manajemen untuk mempertahankan atau meningkatkannya.

Menurut Scanning (1992; 22) Aktiva atau aset merupakan jasa yang akan datang dalam bentuk jasa atau uang dimasa mendatang yang bisa ditukarkan menjadi uang (kecuali jasa yang timbul dari kontrak yang belum dijalankan kedua pihak secara sebanding) yang di dalamnya terkandung kepentingan yang bermanfaat yang dijamin menurut hukum atau keadilan.

\section{METODE}

Jenis data yang penulis gunakan adalah data sekunder yaitu data dan informasi yang telah jadi, berupa laporan dan dokumen yang berkaitan dengan objek penelitian. Pada penelitian ini penulis menggunakan data dokumentasi, dengan menggunakan data skunder time series yaitu data empat tahun terakhir dari awal berdirinya BUMDes tersebut.

Dalam menganalisis penelitian ini, penulis menggunakan metode desktiptif dan kualitatif dengan instrumen-instrumen sebagai berikut:

Metode Deskriptif

Metode Deskriptif adalah penganalisaan data melalui metode merumuskan, menguraikan dan menginterprestasikan berdasarkan telaah pustaka yang terdapat dalam penelitian dan 
literatur sebagai referensi penelitian ini untuk kemudian ditarik sebuah kesimpulan.

Metode Kuantitatif

Untuk mengukur pengaruh dari variabel bebas (jumlah nasabah) dengan variabel terikat (perkembangan aset) akan digunakan analisis regresi linear sederhana dengan rumus sebagai berikut (Umar, 2005:188)

$$
\begin{aligned}
& Y=a+b X \\
& \text { Dimana: } \\
& Y=\text { Subyek variabel terikat yang } \\
& X=\text { Variabel bebas yang }
\end{aligned}
$$

\section{HASIL}

Dalam pendirian BUMDes ini dikenal empat tahapan; Pertama, pemerintah desa dan masyarakat bersepakat mendirikan BUMDes, lalu diadakan Pengelolaan BUMDes dan penetapan Persyaratan Pemegang Jabatan, diadakan pula Monitoring dan Evaluasi, dan yang terakhir diadakan Pelaporan Pertanggungjawaban Pengelola.

Dalam kegiatan harian maka pengelola harus mengacu pada tata aturan yang sudah disepakati bersama sebagaimana yang telah tertuang dalam Anggaran Dasar dan Anggaran Rumah Tangga (AD/ART) BUMDes, serta sesuai prinsip-prinsip tata kelola BUMDes.

Sebagai salah satu lembaga ekonomi yang beroperasi dipedesaan, BUMDes harus memiliki perbedaan dengan lembaga ekonomi pada umumnya. Ini dimaksudkan agar keberadaan dan kinerja BUMDes mampu memberikan kontribusi yang signifikan terhadap peningkatan kesejahteraan warga masyarakat. Dalam penelitian ini peneliti menggunakan dua variabel yaitu jumlah nasabah dengan perkembangan aset.

Aset adalah semua hak yang dapat digunakan dalam operasi perusahaan. Yang dapat dimasukkan ke dalam kolom aset salah satunya adalah gedung atau bangunan. Jadi kalau suatu perusahaan memiliki gedung senilai satu miliar rupiah, maka asset yang dihitung adalah satu miliar rupiah itu. Selain gedung, yang bisa dihitung sebagai asset bisa termasuk: merk dagang, paten teknologi, uang kas, mobil, Aset dipahami sebagai harta total.

Daftar aset dalam neraca disusun menurut tingkat likuiditasnya, mulai dari yang paling likuid hingga yang tidak likuid. Aktiva pada neraca disajikan pada sisi kiri secara berurutan dari atas ke bawah. Penyusunan neraca dimulai dari yang paling likuid (lancar), yaitu mulai dari aktiva lancar, aktiva tetap dan seterusnya. Komponen aktiva lancar dapat dilihat dari "kas, surat-surat berharga, piutang, persediaan, dan sebagainya. Komponen aktiva tetap menurut Kasmir sebagai berikut: "Tanah, bangunan, mesin, kendaraan, peralatan, dan lainnya" Berdasarkan teori di atas aktiva disusun secara berurutan dari mulai yang likuid sampai yang kurang likuid atau yang gampang dengan mudah diuangkan. Bagi manajemen, di dalam membaca neraca, nilai aset perlu dicermati karena menjadi dasar pengukuran prestasi keuangan perusahaan. Ukuran ini menjadi pembanding prestasi sesuatu perusahaan dengan prestasi perusahaan yang lain dalam hal yang sama, apakah lebih baik atau tidak, sehingga dapat menjadi dasar keputusan manajemen untuk mempertahankan atau meningkatkannya.

Berikut ini terlampir perkembangan untuk perkembangan aset pada Badan Usaha Milik Desa (BUMDes) Lestari di Desa Kumain Kecamatan Tandun Kabupaten Rokan Hulu dalam 4 tahun bterakhir.

Tabel 1: Perkembangan Aset BUMDes Lestari

\begin{tabular}{|c|c|c|}
\hline Tahun & Perkembangan Aset $(\mathrm{Rp})$ & Persentase \\
\hline 2013 & 593.546 .118 & - \\
\hline 2014 & 715.246 .250 & $20,50 \%$ \\
\hline 2015 & 1.001 .563 .430 & $40,03 \%$ \\
\hline 2016 & 1.606 .523 .979 & $60,40 \%$ \\
\hline
\end{tabular}

Sumber: BUMDes Lestari, 2017

p.ISSN: $2407-800 \mathrm{X}$

e.ISSN: $2541-4356$ 
Berdasarkan table 1 diatas terlihat bahwa pada tahun 2013 perkembangan aset pada Badan Usaha Milik Desa (BUMDes) Lestari sebesar Rp. 593.546.118 ini dikarenakan pihak Badan Usaha Milik Desa (BUMDes) Lestari memiliki aset berup atanah yang setiap tahunnya mengalami kenaikan harga. Kemudian pada tahun 2014 dan tahun 2015 mengalami kenaikan pada perkembangan aset sebesar Rp. 715.246.250 menjadi 1.001 .563 .430 atau $20,50 \%$ menjadi $50,03 \%$ dari tahun sebelumnya, salah satu penyebab meningkatknya perkembangan aset, Badan Usaha Milik Desa (BUMDes) Lestari sudah mendapatkan nasabah dan sudah mendapat simpatik dari masyarakat dan mulai mendapatkan pasar untuk menjadi nasabah. Kemudian pada tahun 2016 pihak Badan Usaha Milik Desa (BUMDes) Lestari dari perkembangan aset terus mengalami kenaikan bila dibandingkan dengan tahun sebelumnya yaitu sebesar Rp. 1.606.523.979 atau $60,40 \%$. Salah satu penyebab meningkatnya perkembangan aset pada tahun tersebut disebabkan oleh semakin gencarnya Badan Usaha Milik Desa (BUMDes) Lestari dalam promosi sehingga masyarakat semakin banyak untuk menjadi bagian dari Badan Usaha Milik Desa (BUMDes) Lestari.

Nasabah adalah seseorang atau suatu perusahaan yang mempunyai rekening koran atau deposito atau tabungan serupa lainnya pada sebuah bank. Pendapat lain nasabah adalah orang atau sekelompok orang yang melakukan kegiatan transaksi pada sebuah lembaga keuangan atau juga sekelompok individu atau sekelompok orang yang melakukan kerjasama dalam bentuk keuangan. Sesuai uraian diatas penulis menyimpulkan bahwa nasabah BUMDes adalah orang orang atau individu yang mengadakan transaksi simpanan atau pinjaman yang terjadi pada Badan Usaha Milik Desa (BUMDes), sedangkan pada penelitian ini penulis lebih melihat pada nasabah dari segi pinjaman. Banyaknya jumlah nasabah pada Badan Usaha Milik Desa (BUMDes), dapat dilihat melalui data sebagai berikut :
Tabel 2: Perkembangan Jumlah Nasabah BUMDes Lestaris

\begin{tabular}{|c|c|c|}
\hline Tahun & Jumlah Nasabah & Persentase \\
\hline 2013 & 117 & - \\
\hline 2014 & 202 & $72,65 \%$ \\
\hline 2015 & 354 & $75,25 \%$ \\
\hline 2016 & 551 & $55,65 \%$ \\
\hline
\end{tabular}

Sumber : BUMDes Lestari, 2017

Berdasarkan table 2 di atas terlihat bahwa pada tahun 2013 perkembangan jumlah nasabah pada Badan Usaha Milik Desa (BUMDes) Lestari adalah sebanyak 117 orang dimana ini disebabkan pihak Badan Usaha Milik Desa (BUMDes) Lestari, 2017 memulai memasarkan dan memperkenalkan kepada masyarakat dengan merambah kebeberapa media iklan seperti pada Koran, famplet dan lain sebagainya. Kemudian pada tahun 2014 mengalami kenaikan pada jumlah nasabah menjadi 202 orang atau $72,65 \%$ dari tahun sebelumnya, hal ini diiringi oleh semakin banyaknya nasabah yang tertarik untuk meminjam atau menjadi nasabah kepada pihak Badan Usaha Milik Desa (BUMDes) Lestari. Pada tahun 2015 Badan Usaha Milik Desa (BUMDes) Lestari dari segi jumlah nasabah mengalami kenaikan yang pesat bila dibandingkan dengan tahun sebelumnya yaitu sebanyak 354 orang atau meningkat sebesar $75,25 \%$. Pada tahun 2016 Badan Usaha Milik Desa (BUMDes) Lestari mengalami kenaikan lagi pada jumlah nasabah.

\section{PEMBAHASAN}

Pembuktian hipotesis ini digunakan untuk melihat pengaruh variabel bebas terhadap variabel terikatnya. Dimana variabel bebasnya yaitu jumlah nasabah $(\mathrm{X})$ serta variabel terikatnya yaitu perkembangan aset (Y). bedasarkan perhitungan melalui komputer dengan menggunakan SPSS versi 21, maka diperoleh persamaan regresi linear sederhana sebagai berikut :

$$
Y=262164816,689+2343317,410 X
$$


Dari persamaan regresi di atas menunjukkan bahwa pengaruh jumlah nasabah terhadap perkembangan aset adalah positif ditunjukkan oleh nilai koefisien regresi yang bernilai positif. Nilai koefisien regresi sebesar 262164816,689 menjunjukkan bahwa setiap kenaikan jumlah nasabah sebesar satuan-satuan akan meningkatkan perkembangan aset sebesar 262164816,689 satuan. Sedangkan nilai konstanta sebesar 2343317,410 menunjukkan bahwa apabila Badan Usaha Milik Desa (BUMDes) Lestari tidak melakukan atau tidak meningkatkan jumlah nasabah maka perkembangan aset akan diperoleh sebesar 2343317,410 satuan. Artinya disamping jumlah nasabah yang ikut mempengaruhi perkembangan aset masih ada variabel lain yang berpengaruh dalam meningkatkan perkembangan aset pada Badan Usaha Milik Desa (BUMDes) Lestari.

Setelah dilakukan pengolahan data ternyata betul jumlah nasabah berpengaruh terhadap perkembangan aset, dimana besarnya pengaruh jumlah nasabah terhadap perkembangan aset adalah sebesar 97,6\% sedangkan sisanya sebesar $2,4 \%$ dipengaruhi oleh variabel lain diluar variabel penelitian ini.

Maka untuk mengetahui signifikan atau tidaknya pengaruh jumlah nasabah terhadap perkembangan aset dilakukan uji $\mathrm{t}$ dengan tingkat signifikan $5 \%$ diperoleh bahwa nilai t-hitung $=9,038$ lebih besar dari nilai kritisnya atau yang ditunjukkan oleh ttabel sebesar $=2.503$. maka hipotesis dari penelitian ini dapat diterima dan terbukti bahwa jumlah aset berpengaruh signifikan terhadap perkembangan aset pada Badan Usaha Milik Desa (BUMDes) Lestari.

Bila dilihat dari hasil penelitian diatas, Badan Usaha Milik Desa (BUMDes) Lestari bergerak seperti perusahaan lainnya. Badan Usaha Milik Desa (BUMDes) Lestari adalah Badan Usaha yang dimiliki oleh Pemerintah Desa Kumain yang pengelolaanya diserahkan kepada pengelola BUMDes yang telah ditunjuk oleh Pemerintah Desa dengan Kesepakatan dan mufakat melalui proses musyawarah Desa.
BUMDes Lestari desa Kumain sedikitnya mempunyai 3 kegiatan utama, yaitu : 1). Menerima dana dari masyarakat dalam bentuk tabungan, 2). Menyalurkan dana kepada yang membutuhkan dalam bentuk pinjaman, dan 3). Pembiayaan, pembelian barang barang kebutuhan masyarakat melalui pesanan.

Jika diperhatikan kontribusi yang diberikan oleh BUMDes Lestari desa Kumain khususnya dalam hal pembiayaan pinjaman kepada nasabah sangat membantu untuk meningkat pendapatan masyarakat dan ini sangat membantu pemerintah dalam mensejahterakan masyarakat, dari hasil penelitian yang dilakukan diperoleh nilai yang cukup berpengaruh dalam meningkatkan perkembangan aset BUMDes Lestari desa Kumain. Dari peningkatan jumlah nasabah yang melakukan pinjaman ke BUMDes Lestari desa Kumain akan menambahkan pulan perkembangan aset dari tahun ketahun, maka akan terlihat keseimbangan antara variabel yang diteliti yang memberikan kontribusi cukup signifikan, dimana dari perkembangan jumlah nasabah dapat memberikan efek positif bagi BUMDes Lestari desa Kumain. Jadi dapat disimpulkan dengan adanya peningkatan jumlah nasabah yang tinggi akan berpengaruh positif atau sangat signifikan terhadap perkembangan aset pada BUMDes Lestari desa Kumain.

\section{SIMPULAN}

Berdasarkan hasil penelitian dan pembahasan serta analisis yang telah dilakukan pada bab sebelumnya, maka pada bab ini penulis akan menarik kesimpulan dari hasil penelitian mengenai Pengaruh Jumlah Nasabah Peminjam Terhadap Perkembangan Asset Badan Usaha Milik Desa (BUMDes) Lestari di Desa Kumain Kecamatan Tandun Kabupaten Rokan Hulu. Selain itu, penulis juga akan memberikan saran-saran sebagai implikasi dari hasil penelitian ini yang kiranya bermanfaat bagi pihak-pihak yang berkepentingan.

Berdasarkan hasil olahan data,

$$
\text { p.ISSN: 2407-800X e.ISSN: 2541-4356 }
$$


untuk melihat ada atau tidaknya pengaruh jumlah nasabah terhadap perkembangan aset dilakukan uji t dengan tingkat signifikan 5\% diperoleh bahwa nilai t-hitung $=9.038$ lebih besar dari nilai kritisnya atau yang ditunjukkan oleh t-tabel sebesar $=2.503$. maka hipotesis dari penelitian ini dapat diterima dan terbukti bahwa jumlah nasabah berpengaruh signifikan terhadap perkembangan aset pada Badan Usaha Milik Desa (BUMDes) Lestari.

Bedasarkan hasil perhitungan untuk melihat seberapa besar persentase sumbangan variabel bebas jumlah nasabah terhadap perkembangan aset. Setelah dilakukan pengolahan data ternyata betul jumlah nasabah berpengaruh terhadap perkembangan aset, dimana besarnya pengaruh jumlah nasabah terhadap perkembangan aset adalah sebesar 97,6\% sedangkan sisanya sebesar $2,4 \%$ dipengaruhi oleh variabel lain diluar variabel penelitian ini.

\section{DAFTAR RUJUKAN}

Djaslim Saladin, 1994, Dasar-Dasar Manajemen Pemasaran Bank, CV. Rajawali, Jakarta

Pailis, E. A., \& Suroto, B. (2016). The Influence of Partnerships and Selfconcept for the Courage to Take Risks and Their Impact on the Achievements Sought of Small Industries in the City of Pekanbaru. American Journal of Economics, 6(5), 262-269.

Fatkhurahman, F. (2016). Kepuasan Berwirusaha Melalui Kemauan Untuk Berkarya Usaha Industri Kecil. JEBI (Jurnal Ekonomi dan Bisnis Islam), 1(2), 143-153.

Gatot Supramono, 2009, Perbankan dan Kebijakan kredit, Djambata, Jakarta.

Kasmir, 2006, manajemen Perbankan, PT. Rajagrafindo Persada, Jakarta.
Komaruddin 1994, Ensiklopedia Manajemen, Bumi Aksara, Jakarta

Linton,L. 1995, Partnership Modal Ventura, PT.IBEC, Jakarta

Maryunani. 2008. Pembangunan Bumdes dan Pemerdayaan Pemerintah Desa, CV Pustaka Setia, Bandung

Mubyarto (1984) Pembangunan Pedesaan. Yogyakarta, P3PK UGM.

Nurcholis, Hanif (2011) Pertumbuhan dan Penyelenggaraan Pemeritahan Desa. Jakarta, Erlangga.

Peraturan Menteri Dalam Negeri Nomor 39 Tahun 2010 tentang Badan Usaha Milik Desa (c.2). Jakarta, Menteri Dalam Negeri.

Peraturan Pemerintah Nomor 72 Tahun 2005 tentang Desa. Jakarta, Direktorat Jendral Otonomi Daerah.

Seyadi. 2003. Bumdes sebagai Alternatif Lembaga Keuangan Desa. UPP STM YKPN. Yogyakarta

Sulistyani,AT, 2004, Kemitraan dan ModelModel Pemberdayaan. Yogyakarta, Gava Media.

Undang - Undang Nomor 32 Tahun 2004 tentang Pemerintah Daerah. Jakarta, Direktoral Jenderal Otonomi Daerah.

Widjaja, HAW. (2002) Otonomi Daerah dan Daerah Otonom. Jakarta, PT.Raja Grafindo Persada.

Widjaja, HAW. 2002, Pemerintahan Desa/Marga Berdasarkan UndangUndang Nomor 22 Tahun 1999 tentang Pemeritahann Daerah. Jakarta, PT.Raja Grafindo Persada. 